\title{
Structural, biosynthetic and serological cross-reactive elucidation of capsular polysaccharides from Streptococcus pneumoniae serogroup 16
}

Li, Chengxin; Duda, Katarzyna A.; Elverdal, Pernille L.; Skovsted, lan C.; Kjeldsen, Christian; Duus, Jens $\varnothing$.

Published in:

Journal of Bacteriology

Link to article, DOI:

10.1128/JB.00453-19

Publication date:

2019

Document Version

Peer reviewed version

Link back to DTU Orbit

Citation (APA):

Li, C., Duda, K. A., Elverdal, P. L., Skovsted, I. C., Kjeldsen, C., \& Duus, J. Ø. (2019). Structural, biosynthetic and serological cross-reactive elucidation of capsular polysaccharides from Streptococcus pneumoniae serogroup 16. Journal of Bacteriology, 201(20), [e00453-19]. https://doi.org/10.1128/JB.00453-19

\section{General rights}

Copyright and moral rights for the publications made accessible in the public portal are retained by the authors and/or other copyright owners and it is a condition of accessing publications that users recognise and abide by the legal requirements associated with these rights.

- Users may download and print one copy of any publication from the public portal for the purpose of private study or research.

- You may not further distribute the material or use it for any profit-making activity or commercial gain

- You may freely distribute the URL identifying the publication in the public portal 
3 Chengxin $\mathrm{Li}^{\mathrm{a}}$, Katarzyna A. Duda ${ }^{\mathrm{b}}$, Pernille L. Elverdal' ${ }^{\mathrm{c}}$, Ian C. Skovsted ${ }^{\mathrm{c}}$, Christian Kjeldsen ${ }^{\mathrm{a}}$,

4 Jens $\varnothing$. Duus ${ }^{\mathrm{a}, *}$

$5 \quad$ a Department of Chemistry, Technical University of Denmark, Kgs. Lyngby, Denmark

6 b Junior Research Group of Allergobiochemistry, Research Center Borstel, Leibniz Lungenzentrum,

7 Airway Research Center North (ARCN), German Center for Lung Research (DZL), Borstel,

8 Germany

9 ' $S S I$ Diagnostica A/S, Hilleroed, Denmark

*Corresponding author: jduus@kemi.dtu.dk, +45 45252451

\section{Abstract}

Capsular polysaccharides (CPS) are crucial virulence factors of Streptococcus pneumonia. The previously unknown CPS structures of the pneumococcal serogroup 16 (serotype 16F and 16A) were thoroughly elucidated by nuclear magnetic resonance (NMR) spectroscopy and verified by chemical analysis. The following repeat unit structures were determined:

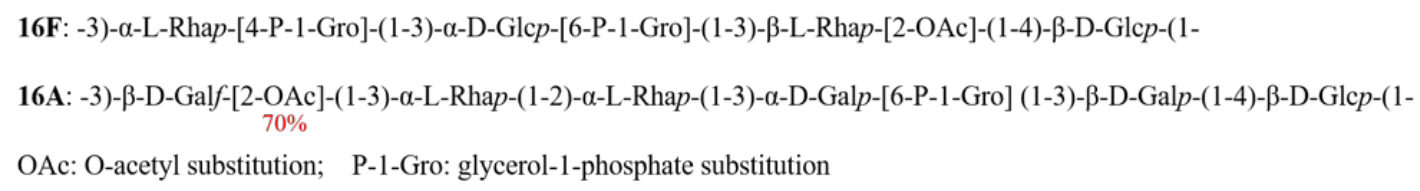

A further analysis of CPS biosynthesis of serotype 16F and 16A, in conjunction with published cps gene bioinformatics analysis and structures of related serotypes, revealed presumable specific function of glycosyltransferase, acetyl transferase, phosphotransferase and polymerase. The 
functions of glycosyltransferase WcxN and WcxT were proposed for the first time, which were assigned to catalyze linkage of $\alpha$-L-Rhap-(1-3)- $\alpha$-D-Glcp and $\alpha$-L-Rhap-(1-2)- $\alpha$-L-Rhap, respectively. Furthermore, since serotype $16 \mathrm{~F}$ was genetically close to serogroup 28, cross-reactions between serogroup 16 and serogroup 28 were studied using diagnostic antisera, which provided further understanding of antigenic properties of CPS and diagnostic antisera. Interestingly, serotype 16F cross-reacted with factor antisera 28b and 11c. Meanwhile, serotype 16A cross-reacted with

27 factor antiserum 11c.

\section{Importance:}

The vaccine pressure against Streptococcus pneumoniae could result in the change of prevalence in carriage and invasive serotypes. As such, it is necessary to monitor the distribution to achieve towards developing future diagnostic tools and vaccines.

\section{INTRODUCTION}

37 Streptococcus pneumoniae is an important encapsulated Gram-positive human pathogen, with 93 38 distinct serotypes reported (1)(2). The capsular polysaccharide (CPS), forming the hydrated outer layer of S. pneumoniae, protects the pathogen from the host immune system, which is the basis for successful vaccines against infections caused by S. pneumoniae. Based on the importance of CPS, it has been extensively studied from basic structure and genetic biosynthesis to immunology.

42 Determination of unknown pneumococcal CPS structures is important to understand the function of 43 biosynthetic genes, enzymes and relationships between structure and antigenicity. The elucidation 
of genetic basis for all capsular types have been completed by sequencing the corresponding DNA stretches (3). While, the structural analysis of the corresponding capsular polysaccharide has remained incomplete.

Serotype $16 \mathrm{~F}$ is not included in any current vaccine, however, in recent years, it was reported as a potential cause of Invasive Pneumococcal Disease (IPD) and increased case-fatality rates in several studies (4)(5)(6)(7)(8). The efficacy of a given vaccine is inherently dependent on the serotype distribution in the target population for the serotype-specific protection of pneumococcal vaccines. Thus, it is important to monitor the epidemiology of pneumococcal serotypes to formulate future pneumococcal vaccines. One study proposed $16 \mathrm{~F}$ as a candidate for higher valency pneumococcal conjugate vaccines (9). However, the CPS structure of serotype 16F and 16A were both unknown, which consequently resulted in ambiguity of the function of related biosynthetic genes and enzymes. from serological perspectives.

\section{RESULTS AND DISCUSSION}

NMR structural analysis of $16 \mathrm{~F}$ and 16A CPS repeat units were conducted mainly in two steps: assignment of individual monosaccharides or residues and connecting the identified structural motifs to yield the repeat unit structure (10). Assignment of individual spin systems were based on $1 \mathrm{D}{ }^{1} \mathrm{H}$ NMR and 2D double quantum filter correlated spectroscopy (DQF-COSY) spectra, total correlation spectroscopy (TOCSY) spectra, 
TOCSY spectra. In addition, heteronuclear 2 bond correlation (H2BC) spectra and heteronuclear multi-bond correlation (HMBC) spectra were used to confirm spin systems, especially in some overlapping regions. Then glycosidic bonds were identified using ${ }^{1} \mathrm{H}-{ }^{13} \mathrm{C}$ HMBC spectra and nuclear Overhauser effect spectroscopy (NOESY) spectra, and similarly were O-acetylated positions. Phosphodiester linkages were determined by ${ }^{1} \mathrm{H}-{ }^{31} \mathrm{P}$ HMBC. Clean in-phase (CLIP) HSQC (11) was used to determine the anomeric configuration of pyranosides (12) . In addition, NMR analysis of the de-O-acetylated (de-OAc) CPS and dephosphorylated (de-P-Gro) CPS was

conducted to simplify spectra and confirm the position of substitutions.

The 16F CPS NMR spectra gave broad lines because of short transverse relaxation times (T2) due to slow molecular tumbling expected from high molecular weight polysaccharides, but could also be partly due to the heterogeneous nature of the sample. Applying higher temperature (333k) and slightly depolymerizing CPS by sonication can increase molecular tumbling rate in order to improve line shapes. Moreover, removal of OAc groups and P-1-Gro substituents also lead to narrower lines as the sample became more homogeneous. There were a relatively strong phosphocholine signal at 3.2/54.5 ppm and other small signals from cell wall polysaccharides (CWPS)(13) in both 16F and 16A CPS NMR spectra.

\section{NMR assignments for serotype 16F CPS repeat unit}

According to $1 \mathrm{D}{ }^{1} \mathrm{H}$ and HSQC spectra of $16 \mathrm{~F}$ CPS, there were four different anomeric signals corresponding to four sugar residues, labelled as $\mathbf{A}, \mathbf{B}, \mathbf{C}$, and $\mathbf{D}$ in order of descending ${ }^{1} \mathrm{H}$ chemical shift (Fig. 1). Furthermore, there also was a downfield signal at 5.634 ppm corresponding to an OAc substitution as well as three methyl signals, two of which corresponded to the 6-position of 6-deoxy sugars as well as one corresponding to an OAc group. Residues $\mathbf{A}$ and $\mathbf{B}$ were both identified as rhamnopyranosides as they had methyl groups at their 6-position and ${ }^{3} J_{\mathrm{H}, \mathrm{H}}$ coupling patterns (Table S1) corresponding to 6-deoxy mannopyranoside configurations. Residue $\mathbf{C}$ was determined to be an 
$\alpha$-glucopyranose according to ${ }^{3} J_{\mathrm{H}, \mathrm{H}}$ coupling pattern. $\mathbf{D}$ was determined to be a $\beta$-glucopyranose, as it only showed large ${ }^{3} J_{\mathrm{H}, \mathrm{H}}$ coupling constants. The ${ }^{3} J_{\mathrm{H} 3 \text {, } \mathrm{H} 4}$ were difficult to measure because of the overlap in both ${ }^{1} \mathrm{H}$ and DQF-COSY spectra. Based on ${ }^{1} J_{\mathrm{H} 1, \mathrm{C} 1}$ measured from CLIP-HSQC, A and C, with ${ }^{1} J_{\mathrm{H} 1, \mathrm{C} 1}$ of about $170 \mathrm{~Hz}$, were identified as $\alpha$-configuration, while $\mathbf{B}$ and $\mathbf{D}$, with ${ }^{1} J_{\mathrm{H} 1, \mathrm{C} 1}$ of about $160 \mathrm{~Hz}$, were $\beta$-configuration(12). The monosaccharide composition analysis showed that $16 \mathrm{~F}$ CPS were composed of rhamnose and glucose in a 1:1 ratio (Table 1), which was consistent with the results of the NMR analysis.

After the monosaccharide units were identified, HMBC and NOESY were used to find the linkage of these monosaccharides (Table 2 and Fig. S1). The anomeric position of $\mathbf{A}$ had HMBC and NOESY correlations with C3, while the anomeric position of $\mathbf{C}$ had correlations with B3. Similarly, there were HMBC and NOESY cross peaks between B1 and D4 and between D1 and A3. Therefore, these four sugar residues make up the backbone of the repeat unit in the order: 3)-A-(13)-C-(1-3)-B-(1-4)-D-(1-. Furthermore, according to ${ }^{31} \mathrm{P}$ and ${ }^{1} \mathrm{H}-{ }^{31} \mathrm{P}$ HMBC spectra, there were two phosphate groups attached to the backbone. One connected to the 4-position of the $\alpha$-rhamnose A and another attached to the 6-position of the $\alpha$-glucose $\mathbf{C}$. The phosphorylated positions were confirmed by NMR analysis of de-P-Gro 16F CPS, as the chemical shifts of A4 (4.110/75.72 ppm) and C6 (4.058/64.70 ppm) in sonicated CPS moved upfield to 3.604/71.38 ppm and 3.772/3.779/60.78 ppm in de-P-Gro 16F CPS, respectively. The $\beta$-rhamnose B was 2-OAc substituted according to HMBC correlations between carbonyl of the OAc group and B2 proton, which could explain an extremely downfield proton chemical shift of B2 at $5.634 \mathrm{ppm}$. Moreover, in the NMR spectra of de-OAc 16F CPS, the signals from the acetyl group disappeared and the $\mathbf{B} 2$ proton signal moved upfield from 5.634 ppm to 4.269 ppm. Furthermore, there were three additional sharp and intense signals, two $\mathrm{CH}_{2}$ groups and one $\mathrm{CH}$ group, in sonicated $\mathrm{CPS}$ and deP-Gro CPS, which arose from free glycerol. These signals had almost identical chemical shifts and 
line shapes to those detected from a reference sample of glycerol in $\mathrm{D}_{2} \mathrm{O}$ (Fig. S2) and did not show any correlations to other units. The free glycerol could be generated during strong sonication.

Therefore, one needs to pay extra attention when using strong sonication to depolymerize large polysaccharides.

Based on the above analysis, the repeat unit of serotype 16F CPS was determined to be a tetrasaccharide: -3)- $\alpha$-L-Rhap-[4-P-1-Gro]-(1-3)- $\alpha$-D-Glcp-[6-P-1-Gro]-(1-3)- $\beta$-L-Rhap-[2-OAc]-(1-

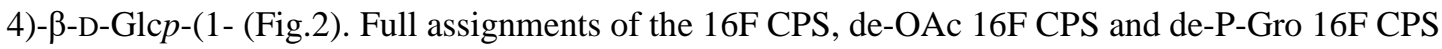
repeat unit is given in Table 2 .

\section{NMR assignments for serotype 16A CPS repeat unit}

$1 \mathrm{D}{ }^{1} \mathrm{H}$ and HSQC spectra of 16A CPS contained eight different anomeric signals. However, the intensity of these anomeric signals varied, and it turned out to be due to partial 2-OAc substitution on a single position (Fig. 3). Moreover, NMR analysis of de-O-acetylated 16A CPS showed only six anomeric signals, which indicated that 2-OAc substitution affected nearby anomeric signals. The monosaccharide units were labelled $\mathbf{A}, \mathbf{B}, \mathbf{C}, \mathbf{D}, \mathbf{E}$ and $\mathbf{F}$ in order of descending ${ }^{1} \mathrm{H}$ chemical shift. As A was only partially 2-OAc substituted, A without 2-OAc substitution was labelled as A'. Similarly, the anomeric position of $\mathbf{E}$ was affected by the acetylation of $\mathbf{A}$, and as such the corresponding monosaccharide unit in the approximately 30\% non-acetylated repeat unit was labelled as E'.

Furthermore, three methyl groups were observed, two of which had almost identical chemical shift corresponding to the methyl of 6-deoxy sugars, and the third one was the methyl of an acetyl group.

A was identified as a galactose, approximately $70 \%$ of which was 2-OAc substituted according to integration of ${ }^{1} \mathrm{H}-\mathrm{NMR}$ anomeric signals. The ${ }^{3} J_{\mathrm{H}, \mathrm{H}}$ coupling constants of $\mathbf{A}$ did not show regular pattern as pyranose sugar, and based on the chemical shifts $\mathbf{A}$ was identified as a $\beta$-galactofuranose 
(14)(15). This 2-OAc substitution of A would explain the downfield shifted proton chemical shift of A2 at 5.155 ppm. The de-OAc 16A CPS spectra became far simpler compared to native 16A CPS, as signals caused by the partial O-acetylation disappeared. The anomeric region of de-OAc 16A CPS showed only six signals with almost identical integrals in the ${ }^{1} \mathrm{H}$ spectrum. The chemical shift of A2 moved upfield from 5.155/82.45 ppm to 4.342/80.45 ppm (Table 3). B and D were both identified as rhamnopyranosides, because of the methyl groups at their 6-positions and the ${ }^{3} J_{\mathrm{H}, \mathrm{H}}$ coupling constants that corresponded to 6-deoxy mannopyranose configurations. $\mathbf{C}$ and $\mathbf{F}$ was identified as an $\alpha$ - and $\beta$-galactopyranoside, respectively, according to their ${ }^{3} J_{\mathrm{H}, \mathrm{H}}$ coupling constants (Table S1) and chemical shifts. The 6-position of $\mathbf{C}$ was connected to a glycerol-1phosphate substitution according to ${ }^{1} \mathrm{H}-{ }^{31} \mathrm{P}$ HMBC, which can explain the relatively downfield chemical shift 3.960/64.46 ppm at C6 compared to 3.704/61.24 ppm in de-P-Gro 16A CPS. E was determined to be a $\beta$-glucopyranose as it only had large ${ }^{3} J_{\mathrm{H}, \mathrm{H}}$ coupling constants. Based on the ${ }^{1} J_{\mathrm{H} 1}$, C1 coupling constants of approximately $170 \mathrm{~Hz}$, measured from CLIP-HSQC, the two rhamnosides $\mathbf{B}$ and $\mathbf{D}$ were identified as having $\alpha$-configuration. Additionally, the CLIP-HSQC was also used to confirm the anomeric configurations of $\mathbf{C}, \mathbf{E}$ and $\mathbf{F}$ with ${ }^{1} J_{\mathrm{H} 1, \mathrm{C} 1}$ coupling constants of approximately 170, 160 and $160 \mathrm{~Hz}$, respectively. The anomeric configurations are in agreement

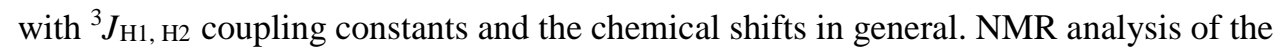
monosaccharide repeat units were in agreement with the results of the monosaccharide composition analysis: rhamnose : galactose : glucose in approximately a $2: 3: 1$ ratio (Table 1). Furthermore, in the HMBC and NOESY spectra (Fig. S3), cross peaks of A1 with D3, D1 with B2, B1 with C3, C1 with F3, F1 with E4 and E1 with A3 revealed linkages of these monosaccharide units. So, these six sugars constitute a linear backbone of the 16A repeat unit in the sequence: 3)-A-(1-3)-D-(1-2)-B-(13)-C-(1-3)-F-(1-4)-E-(1-. Thus, the repeat unit of serotype 16A CPS were determined to be a hexasaccharide with the following structure: -3)- $\beta$-D-Galf-[2-OAc](70\%) -(1-3)- $\alpha$-L-Rhap-(1-2)- $\alpha-$ 
L-Rhap-(1-3)- $\alpha-D-G a l p-[(6-P-1)-G r o] ~(1-3)-\beta-D-G a l p-(1-4)-\beta-D-G l c p-(1-$ (Fig.2). The full assignment of the 16A CPS, de-OAc, de-P-Gro 16A CPS repeat unit is given in Table 3.

The ${ }^{13} \mathrm{C}$ chemical shift assignments of $16 \mathrm{~F}$ and $16 \mathrm{~A}$ CPS also supported glycosidic linkage sites determined by HMBC/NOESY, as all substituted positions had downfield chemical shifts compared to the same unsubstituted position (16). The assigned chemical shifts of de-P-Gro 16F and 16A CPS are in good agreement with those calculated by CASPER(17).

\section{Genetic elucidation of serotype 16F and 16A CPS biosynthesis.}

Biosynthesis of pneumococcal serotype 16F and 16A CPS use the Wzy-dependent mechanism. A summary of 16F and 16A CPS biosynthetic genes, their functions and related serotypes are shown in Table 4, which is based on published genetic sequence data, bioinformatics analysis and CPS structures (3)(18)(19)(1). The cps loci of 16F and 16A did not show high similarity(Fig.4). They have similar conserved regulatory genes cpsABCD (wzg, wzh, wzd and wze), the initial glucosyl-1phosphate transferase gene $(w c h A)(20)$ and d-TDP L-rhamnose pathway gene $(r m l A, r m l C, r m l B$, $r m l D)$. Gene for biosynthesis of glycerol-1-phosphate $(g c t)$ were present in both 16F and 16A with 77\% identities in BLASTp alignment (21). The presences of these similar genes indicated that $16 \mathrm{~F}$ and 16A CPS both contain glucose, rhamnose and glycerol-1-phosphate in their repeat unit structures. However, genes for synthesis of galactofuranose $(g l f)$ presented in serotype 16A but not in 16F. Moreover, they have significantly different glycosyltransferase (GTs) genes and oligosaccharide repeat unit polymerases (Wzy). The Wzy27 in 16F and Wyz15 in 16A showed only 28\% identities in BLASTp comparison. According to 16F and 16A CPS structures, Wzy27 is assigned to polymerize at $\beta$-D-Glcp-(1-3)- $\alpha-\mathrm{L}-\mathrm{Rhap}$, while Wzy15 is assigned to polymerize at $\beta$-DGlcp-(1-3)- $\beta-\mathrm{D}-\mathrm{Gal} f$.

The cps locus of 16F contained three GT genes. The GT (WchF) has been shown to be encoding the $\beta-1-4$ rhamnosyltransferase for addition of the second sugar(22). The GT gene (wciU) in $16 \mathrm{~F}$ cps 
locus, also present in serogroup 18, which added $\alpha$-D-Glcp or $\alpha$-D-GlcNAc to the 3-position of $\beta$-LRhap(19). Therefore, the only unassigned GT (WcxN) should be responsible for addition of $\alpha$-LRhap to the 3-position of $\alpha$-D-Glcp, based on the $16 \mathrm{~F}$ CPS structure we determined in this paper. The putative glycerol phosphotransferase(WcxP) and putative LicD-family phosphotransferase(WcxQ) were responsible for addition of Gro-1-P substitution to the 4-position and 6-position of $\alpha$-D-Glcp and $\alpha$-L-Rhap, respectively, but it was hard to distinguish which specific linkage catalyzed either one of them was responsible for. The WcxM, a putative acetyl transferase, catalyzed O-acetylation at the 2-position of $\beta$-L-Rhap, which was consistent with serotype 18F(1)(23).

Serotype 16A cps locus had five GT genes. The GT (WchK) that is found in 13 different serotypes, was assigned as $\beta$-1-4-galactosyltransferase and $\mathrm{WchJ}$ was suggested to enhance activity of WchK(18)(24). The WcyK, also found in serogroup 11(25), catalyzed linkage of $\alpha$-D-Galp-(1-3)- $\beta$ D-Galp. The WcxS catalyzed the linkage of $\alpha$-L-Rhap-(1-3)- $\alpha$-D-Galp, which were shown for serotype 45(19). The WciB, present in 25 pneumococcal serotypes(Table 4), was assigned as $\beta$-1-3galactofuronosyl transferase (26)(27)(Table 4). Thus, the only unassigned GT(WcxT), by process of elimination, was assigned to be responsible for catalyzing the linkage of $\alpha$-L-Rhap-(1-2)- $\alpha$-L-Rhap . The WciG, a putative acetyl transferase, catalyzed 2-O-acetylation at $\beta$-D-Galf(28)(29)(27) (30). The WcxR is putative LicD-family phosphotransferase which was assigned to catalyze phosphorylation at the 6-position of $\alpha$-D-Galp. The analysis of the biosynthesis of 16F and 16A CPS was in an agreement with determined CPS repeat unit structure and functions of related genes reported in the literature.

When compared to other serogroups, $16 \mathrm{~F}$ cps locus showed high similarity to serotype $28 \mathrm{~A}$ and $28 \mathrm{~F}$ and it was in the same subcluster of cluster 2 (18)(23)(Fig. 4). Not only containing the same conserved regulatory genes, they have highly similar WchA, GTs, acetyl transferase (WcxM) and 
flippase (Wzx). Main differences in 28F and 28A cps loci were glycerol-2-phosphate biosynthetic genes (gtp1, gtp2, gtp3), compared to glycerol-1-phosphate (gct) in 16F (Fig.4). Thus, the repeat unit structure of 16F CPS should have similarities to 28F and 28A CPS structure, which are unfortunately both unknown.

\section{Serological cross-reactions of diagnostic antisera between serogroup 16 and other serotypes}

When serotyping $S$. pneumoniae, serogroup 16 reacts with pool antiserum $\mathrm{D}$ and was identified by group antisera 16 . Furthermore, factor antisera $16 \mathrm{~b}$ and $16 \mathrm{c}$ was used to determine serotype $16 \mathrm{~F}$ and 16A (Table 5). Positive Quellung reactions were observed between serotype 16F and 16A and factor antiserum 11c. Factor antiserum 11c reacted with serotype 11A, 11C and 11D and is reported to bind to P-Gro and OAc groups (25). Moreover, the cross-reaction between serotype 16F and factor serum 11d was previously observed (18). These cross-reactions indicated similar antigenic properties among them. However, the cps gene locus of serotypes 11A do not show high similarity to $16 \mathrm{~F}$ cps locus apart from regulatory genes, wchA and gct(Fig.4), while 16A shared some similar GTs (WchJ, WchK and WcyK) with serogroup 11. The common parts of the 16F CPS repeat unit structure compared with that of $11 \mathrm{~A}$, are that they consist of a linear tetrasaccharide backbone with glycerol-1-phosphate branches and O-acetyl substitution. The O-acetylation was reported to be crucial to the antigenicity of serogroup 11(25)(31). The cross-reactions between group 16 and factor antiserum 11c confirmed that factor 11c epitope was associated with P-1-Gro and OAc groups. Serotype $16 \mathrm{~F}$ cross-reacted with factor antiserum $28 \mathrm{~b}$, which was used for serotyping $28 \mathrm{~F}$. Thus, it can be predicted that the CPS structure of 28F might be similar to $16 \mathrm{~F}$, as they have highly similar cps genes and common serological activity. No cross-reaction was observed between factor antiserum 11c and serotype 28F, which has genes to express P-2-Gro synthase, indicating that factor antiserum 11c might react specifically to P-1-Gro and not P-2-Gro. Additionally, serotype 28F and 28A reacted with factor antiserum 23d, which is used for serotyping 23B. CPS structures of group 
23 all contain P-2-Gro(32). However, Factor antiserum 23d only reacts with serotype 23B of

serogroup 23. Thus, it suggests that there might be other similar structural properties other than P-2-

237 Gro between serogroup 28 and serotype 23B. However, these assumptions about serogroup 28 need

238 further structural information to be confirmed.

\section{Summary of results}

240 The CPS repeat unit structures of serotype 16F and 16A were elucidated using NMR spectroscopy

241 and chemical analysis (Fig. 2), which provide first comprehensive understanding of serogroup 16

242 CPS. Furthermore, based on the determined CPS structures, a comparison analysis of CPS

243 biosynthesis of serotype $16 \mathrm{~F}$ and $16 \mathrm{~A}$ with related serotypes that share same biosynthetic genes

244 revealed functions of previously unknown glycosyltransferases WcxN and WcxT (Table 4). Finally,

245 the serogroup 16 CPS were subjected to serological studies to determine any relevant cross-

246 reactions with antisera from the genetically similar serogroup 28, where it was shown that the CPS

247 of serotype $16 \mathrm{~F}$ and $28 \mathrm{~F}$ have similar antigenic properties, as they both react with factor serum $28 \mathrm{~b}$

248 which is used for 28F serotyping. Thus, it could be predicted that the CPS structure of serotype 28F

249 should be similar to serotype $16 \mathrm{~F}$, since they have highly similar cps genes and serological

250 behavior.

251

MATERIALS AND METHODS

252

Sample preparation

253 Purified pneumococcal capsular polysaccharide (CPS) from serotypes 16A and 16F, as well as

254 rabbit antisera, were produced by SSI Diagnostica, Hillerod, Denmark. The polysaccharide samples

255 were dissolved in $\mathrm{D}_{2} \mathrm{O}$ (99.9\%, Sigma) to concentrations of approximately 1.5\% w/v (10 mg in 600

$256 \mu \mathrm{L})$. 
Ultra sonicated 16F CPS were obtained by sonication of the CPS (10mg in $5 \mathrm{~mL} 2 \mathrm{M} \mathrm{KCl}$ ) using a

258 LABSONIC ${ }^{\circledR}$ P ultrasonic homogenizer with a $3 \mathrm{~mm}$ Probe for 2 hours under an ice bath,

259 following this it was desalted and concentrated using centrifugal filters (Amicon ${ }^{\circledR}$ Ultra-4, $3 \mathrm{kDa}$ ).

De-OAc and de-P-Gro were performed using methods described by Richards and Perry(33). De-

OAc removed only acetyl groups, while de-P-Gro removed both acetyl and glycerophosphate groups. De-OAc CPS were obtained by treating approximately 5-10 mg of each polysaccharide with $1 \mathrm{~mL}$ of a $0.2 \mathrm{M} \mathrm{NaOH}$ in $\mathrm{D}_{2} \mathrm{O}$ solution at room temperature for $2 \mathrm{~h}$, which was subsequently neutralized with 2M HCl, followed by desalting and removal of residuals using centrifugal filters (Amicon ${ }^{\circledR}$ Ultra-4, $3 \mathrm{kDa}$ ). Dephosphorylated CPS were generated by treating approximately 10 mg of each CPS in $2 \mathrm{~mL}$ of $1 \mathrm{M} \mathrm{NaOH}$, containing a trace amount of sodium borohydride, at 100

${ }^{\circ} \mathrm{C}$ for $4 \mathrm{~h}$ in screw-capped glass tubes filled with nitrogen. Then the solutions were cooled in an ice bath and neutralized with acetic acid, followed by desalting and removal of residuals using centrifugal filters (Amicon ${ }^{\circledR}$ Ultra-4, $10 \mathrm{kDa}$ ). Finally, these samples were transferred to 5 or $3 \mathrm{~mm}$ NMR tubes.

\section{NMR spectroscopy}

NMR spectroscopy were used to determine repeat unit structures of serotypes 16A and 16F CPS.

The NMR experiments were carried out on an a Bruker Avance III (799.90 MHz for 1H and 201.14 $\mathrm{MHz}$ for $\left.{ }^{13} \mathrm{C}\right)$ equipped with a $5 \mathrm{~mm}$ TCI $1 \mathrm{H} /\left({ }^{13} \mathrm{C},{ }^{15} \mathrm{~N}\right)$ cryoprobe or a Bruker AVANCE $600 \mathrm{MHz}$ instrument with 5 mm SmartProbe BB(F)-H-D $\left({ }^{15} \mathrm{~N}-{ }^{31} \mathrm{P},{ }^{1} \mathrm{H},{ }^{19} \mathrm{~F}\right)$.

All spectra of 16A CPS were recorded at $313 \mathrm{~K}$. While 16F CPS spectra were recorded at 333K or 323K. The assignments of $16 \mathrm{~A}$ and $16 \mathrm{~F}$ CPS repeat units were performed using the following experiments: $1 \mathrm{D}{ }^{1} \mathrm{H}$ and ${ }^{31} \mathrm{P}$ and the 2D NMR spectra, including DQF-COSY, TOCSY with $80 \mathrm{~ms}$ mixing time, NOESY with 200-400 ms mixing time, HSQC, HMBC optimized for $8 \mathrm{~Hz}$ long range 
coupling constants, ${ }^{1} \mathrm{H}-{ }^{13} \mathrm{C}$ HSQC-TOCSY with 80 ms mixing time, CLIP-HSQC and ${ }^{1} \mathrm{H}-{ }^{31} \mathrm{P}$

HMBC. Experiments were conducted with standard gradient enhanced Bruker pulse sequences, except CLIP-HSQC(11).

NMR spectra were processed with Topspin 3.5 (Bruker) using extensive zero filling in all dimensions. The one-dimensional ${ }^{1} \mathrm{H}$ spectra were processed with an exponential window function with a line broadening of $0.3 \mathrm{~Hz}$ for ${ }^{1} \mathrm{H}$ spectra. All 2D spectra were processed with shifted sine bell window functions in both dimensions. All spectra were referenced to residual cell wall polysaccharide phosphocholine signals $\left({ }^{1} \mathrm{H} 3.2 \mathrm{ppm}\right.$ and ${ }^{13} \mathrm{C} 54.5 \mathrm{ppm}$ and the shielded ${ }^{31} \mathrm{P}$ signal at $1.30 \mathrm{ppm})(13)$.

\section{General chemical analysis}

The monosaccharide composition was determined by GC after hydrolysis (34) (2 M TFA at 120

$\left.{ }^{\circ} \mathrm{C}, 2 \mathrm{~h}\right)$, addition of xylose as internal standard, reduction $\left(\mathrm{NaBH}_{4}, 16 \mathrm{~h}\right.$ in the dark) and peracetylation (acetic anhydride and pyridine (1:1) $85^{\circ} \mathrm{C}, 10 \mathrm{~min}$, twice). GC analysis was performed on a HP 5890 (series II) gas chromatograph with a flame-ionization detector and a column (30 m $\times 0.25 \mathrm{~mm} \times 0.25 \mu \mathrm{m}$ film thickness, Agilent) of 5\% phenylmethylsiloxane (HP5MS); helium was used as carrier gas (70 kPa). The temperature in GLC was $150^{\circ} \mathrm{C}$ for $3 \mathrm{~min}$, and then increased with $3^{\circ} \mathrm{C} / \mathrm{min}$ to $320^{\circ} \mathrm{C}$. A mixture of standard monosaccharides was used for sugar identification and xylose for quantification.

Methylation was performed using Ciucanu-Kerek's method (35). Prior this the removal of phosphate from CPS samples was done by using $48 \% \mathrm{HF}$ for $48 \mathrm{~h}$ at $4{ }^{\circ} \mathrm{C}$, followed by removal of HF by evaporation under $\mathrm{N}_{2}$ while suspended in DMSO for $16 \mathrm{~h}$ at $60^{\circ} \mathrm{C}$, and then methylated with iodomethane in the presence of $\mathrm{NaOH}$. The product was hydrolyzed with $4 \mathrm{M}$ TFA for $4 \mathrm{~h}$ at 
$100{ }^{\circ} \mathrm{C}$, reduced with $\mathrm{NaBD}_{4}$ and peracetylated with acetic anhydride in pyridine. Partially methylated acetylated alditols were analyzed by GC-MS.

The content of total phosphate was determined by colorimetric analysis according to Lowry et al(36). The samples were subjected to digestion reagent (30.6 mL conc. $\mathrm{H}_{2} \mathrm{SO}_{4}, 6.7 \mathrm{~mL} \mathrm{70 \%}$ $\mathrm{HClO}_{4}$ and $62.7 \mathrm{~mL} \mathrm{H}_{2} \mathrm{O}$ ) at $100{ }^{\circ} \mathrm{C}$ for $1 \mathrm{~h}$ and then at $165^{\circ} \mathrm{C}$ for $2 \mathrm{~h}$. Subsequently, it was cooled down to room temperature and freshly prepared color reagent was added (1 mL $1 \mathrm{M}$ sodium acetate, $1 \mathrm{~mL} 2.5 \%$ ammonium molybdate solution, $7 \mathrm{~mL} \mathrm{H}{ }_{2} \mathrm{O}, 1 \mathrm{~mL}$ freshly prepared ascorbic acid; $37^{\circ} \mathrm{C}$ for $90 \mathrm{~min}$ ). The extinction of the ammonium phosphomolybdate complex was measured at $\lambda=820$ nm (HELIOS BETA 9423 UVB 1002E spectrophotometer, Thermo Electron Ltd., Altrincham, Cheshire, UK). For quantification, $5 \mathrm{mM} \mathrm{Na}_{2} \mathrm{HPO}_{4}$ solution was used as external standard.

The absolute configuration of Rha and Glc was determined by GLC (37), by comparison with authentic standards of the acetylated O-[(R)-2-Octyl] glycoside after methanolysis (0.5 M $\mathrm{HCl} / \mathrm{MeOH}, 85^{\circ} \mathrm{C}, 3.5 \mathrm{~h}$ ), butanolysis (2 M HCl/(R)-2-Octanol, $65^{\circ} \mathrm{C}, 4 \mathrm{~h}$ ) and peracetylation (85 $\left.{ }^{\circ} \mathrm{C}, 10 \mathrm{~min}\right)$. The absolute configuration of Gal was determined by GLC, by comparison with authentic standards, of the acetylated O-[(S)-2-butyl] glycoside after methanolysis (2M HCl/MeOH, $85^{\circ} \mathrm{C}, 45 \mathrm{~min}$ ), butanolysis (2 M HCl/(S)-2-Butanol, $65^{\circ} \mathrm{C}, 4 \mathrm{~h}$ ) and peracetylation( $\left.85^{\circ} \mathrm{C}, 10 \mathrm{~min}\right)$.

\section{Genetic analysis of serogroup 16}

The published cps loci sequences (accession number of serotype 16F, 16A, 28F, 28A, 11A:

CR931668.1, CR931667.1, CR931693.2, CR931692.1, CR931653.1, respectively) have been downloaded from GenBank (https://www.ncbi.nlm.nih.gov/nuccore). Pairwise protein sequence identity has been assessed using BLASTp. Comparison of similarities of the gene products (TBLASTX) of the cps biosynthetic loci was performed by the Artemis comparison tool (ACT)(38). 
The Quellung reaction was performed at SSI Diagnostica using factor antisera (SSI Diagnostica A/S, Hilleroed, Denmark). For the Quellung reaction, bacteria were grown in horse blood agar plate (SSI Diagnostica A/S, Hilleroed, Denmark) overnight. $2-4 \mu \mathrm{L}$ of culture was added onto a glass slide and mixed with the same amount of factor antisera. The mixture was then observed for capsule swelling reaction in a phase contrast microscope.

\section{ACKNOWLEDGEMENTS}

The $800 \mathrm{MHz}$ NMR spectra were recorded on the NMR Center-DTU, supported by the VIllum Fondation. C.L. appreciate the financial support of China Scholarship Council (PhD scholarship No. 201708310119) and Oticon Fonden for financial support during her external stay in Research Center Borstel. We thank Kasper Enemark-Rasmussen for excellent technical assistance with NMR instrument setup, Katharina Jakob (Research Center Borstel) for general chemical analysis and Katrine Helander Pedersen for serological test.

\section{REFERENCE}

1. Geno KA, Gilbert GL, Song JY, Skovsted IC, Klugman KP, Jones C, Konradsen HB, Nahm MH. 2015. Pneumococcal capsules and their types: Past, present, and future. Clin Microbiol Rev 28:871-899.

2. Kjeldsen C, Slott S, Elverdal PL, Sheppard CL, Kapatai G, Fry NK, Skovsted IC, Duus J. 2018. Discovery and description of a new serogroup 7 Streptococcus pneumoniae serotype, 7D, and structural analysis of 7C and 7D. Carbohydr Res.

3. Bentley SD, Aanensen DM, Mavroidi A, Saunders D, Rabbinowitsch E, Collins M, Donohoe K, Harris D, Murphy L, Quail MA, Samuel G, Skovsted IC, Kaltoft MS, Barrell B, Reeves PR, Parkhill J, Spratt BG. 2006. Genetic Analysis of the Capsular Biosynthetic Locus from All 90 Pneumococcal Serotypes. PLoS Genet 2:e31. 
4. Grabenstein JD, Musey LK. 2014. Differences in serious clinical outcomes of infection caused by specific pneumococcal serotypes among adults. Vaccine 32:2399-2405.

5. Harboe ZB, Thomsen RW, Riis A, Valentiner-Branth P, Christensen JJ, Lambertsen L, Krogfelt KA, Konradsen HB, Benfield TL. 2009. Pneumococcal serotypes and mortality following invasive pneumococcal disease: A population-based cohort study. PLoS Med 6.

6. Jansen AGSC, Rodenburg GD, van der Ende A, van Alphen L, Veenhoven RH, Spanjaard L, Sanders EAM, Hak E. 2009. Invasive Pneumococcal Disease among Adults: Associations among Serotypes, Disease Characteristics, and Outcome. Clin Infect Dis 49:e23-e29.

7. Horácio AN, Diamantino-Miranda J, Aguiar SI, Ramirez M, Melo-Cristino J. 2013. The Majority of Adult Pneumococcal Invasive Infections in Portugal Are Still Potentially Vaccine Preventable in Spite of Significant Declines of Serotypes 1 and 5. PLoS One 8:1-9.

8. Luján M, Gallego M, Belmonte Y, Fontanals D, Vallès J, Lisboa T, Rello J. 2010. Influence of pneumococcal serotype group on outcome in adults with bacteraemic pneumonia. Eur Respir J 36:1073-1079.

9. Marsh RL, Smith-Vaughan H, Beissbarth J, Hare K, Kennedy M, Wigger C, Mellon G, Stubbs E, Gadil JR, Pettit A, Mackenzie G, Tipakalippa P, Morris PS, Leach AJ. 2007. Molecular characterisation of pneumococcal serotype 16F: Established predominant carriage and otitis media serotype in the 7vPCV era. Vaccine 25:2434-2436.

10. Duus J, Gotfredsen CH, Bock K. 2000. Carbohydrate structural determination by NMR spectroscopy: modern methods and limitations. Chem Rev 100:4589-4614.

11. Enthart A, Freudenberger JC, Furrer J, Kessler H, Luy B. 2008. The CLIP/CLAP-HSQC: Pure absorptive spectra for the measurement of one-bond couplings. J Magn Reson 192:314- 
370

12. Bock K, Pedersen C. 1974. A study of ${ }^{13} \mathrm{CH}$ coupling constants in hexopyranoses. J Chem Soc Perkin Trans 2 293-297.

13. Skovsted IC, Kerrn MB, Sonne-Hansen J, Sauer LE, Nielsen AK, Konradsen HB, Petersen BO, Nyberg NT, Duus J. 2007. Purification and structure characterization of the active component in the pneumococcal 22F polysaccharide capsule used for adsorption in pneumococcal enzyme-linked immunosorbent assays. Vaccine 25:6490-6500.

14. Agrawal PK. 1992. Nmr Spectroscopy in the Structural Elucidation Oligosaccharides and Glycosides. Phytochemistry 31:3307-3330.

15. Abeygunawardana C, Bush CA, Cisar JO. 1991. Complete Structure of the Cell Surface Polysaccharide of Streptococcus oralis C104: A 600-MHz NMR Study. Biochemistry 30:8568-8577.

16. Shashkov AS, Lipkind GM, Knirel YA, Kochetkov NK. 1988. Stereochemical factors determining the effects of glycosylation on the13C chemical shifts in carbohydrates. Magn Reson Chem 26:735-747.

17. Lundborg M, Widmalm G. 2011. Structural analysis of glycans by NMR chemical shift prediction. Anal Chem 83:1514-1517.

18. Mavroidi A, Aanensen DM, Godoy D, Skovsted IC, Kaltoft MS, Reeves PR, Bentley SD, Spratt BG. 2007. Genetic relatedness of the Streptococcus pneumoniae capsular biosynthetic loci. J Bacteriol 189:7841-7855.

19. Aanensen DM, Mavroidi A, Bentley SD, Reeves PR, Spratt BG. 2007. Predicted functions and linkage specificities of the products of the Streptococcus pneumoniae capsular 
biosynthetic loci. J Bacteriol 189:7856-7876.

20. Pelosi L, Boumedienne M, Saksouk N, Geiselmann J, Geremia RA. 2005. The glucosyl-1phosphate transferase WchA (Cap8E) primes the capsular polysaccharide repeat unit biosynthesis of Streptococcus pneumoniae serotype 8. Biochem Biophys Res Commun 327:857-865.

21. Zhang Z, Schwartz S, Wagner L, Miller W. 2000. A Greedy Algorithm for Aligning DNA Sequences. J Comput Biol 7:203-214.

22. James DBA, Yother J. 2012. Genetic and Biochemical Characterizations of Enzymes Involved in Streptococcus pneumoniae Serotype 2 Capsule Synthesis Demonstrate that Cps2T (WchF) Catalyzes the Committed Step by Addition of $\beta 1-4$ Rhamnose, the Second Sugar Residue in the Repeat Unit. J Bacteriol.

23. Mostowy RJ, Croucher NJ, De Maio N, Chewapreecha C, Salter SJ, Turner P, Aanensen DM, Bentley SD, Didelot X, Fraser C. 2017. Pneumococcal Capsule Synthesis Locus cps as Evolutionary Hotspot with Potential to Generate Novel Serotypes by Recombination. Mol Biol Evol 34:2537-2554.

24. Kolkman MAB, Van Der Zeijst BAM, Nuijten PJM. 1997. Functional analysis of glycosyltransferases encoded by the capsular polysaccharide biosynthesis locus of streptococcus pneumoniae serotype 14. J Biol Chem 272:19502-19508.

25. Calix JJ, Nahm MH, Zartler ER. 2011. Elucidation of structural and antigenic properties of pneumococcal serotype 11A, 11B, 11C, and 11F polysaccharide capsules. J Bacteriol 193:5271-5278.

26. Lin FL, Vinogradov E, Deng C, Zeller S, Phelan L, Green BA, Jansen KU, Pavliak V. 2014. 
Structure elucidation of capsular polysaccharides from Streptococcus pneumoniae serotype 33C, 33D, and revised structure of serotype 33B. Carbohydr Res 383:97-104.

27. Calix JJ, Porambo RJ, Brady AM, Larson TR, Yother J, Abeygunwardana C, Nahm MH. 2012. Biochemical, genetic, and serological characterization of two capsule subtypes among Streptococcus pneumoniae serotype 20 strains: Discovery of a new pneumococcal serotype. J Biol Chem 287:27885-27894.

28. Geno KA, Bush CA, Wang M, Jin C, Nahm MH, Yang J. 2017. WciG O-Acetyltransferase Functionality Differentiates Pneumococcal Serotypes 35C and 42. J Clin Microbiol 55:27752784.

29. Geno KA, Saad JS, Nahm MH. 2017. Discovery of Novel Pneumococcal Serotype 35D, a Natural WciG-Deficient Variant of Serotype 35B. J Clin Microbiol 55:1416-1425.

30. Lin FL, Vinogradov E, Deng C, Zeller S, Phelan L, Green BA, Jansen KU, Pavliak V. 2014. Structure elucidation of capsular polysaccharides from Streptococcus pneumoniae serotype 33C, 33D, and revised structure of serotype 33B. Carbohydr Res 383:97-104.

31. Calix JJ, Brady AM, Du VY, Saad JS, Nahma MH. 2014. Spectrum of pneumococcal serotype 11A variants results from incomplete loss of capsule O-acetylation. J Clin Microbiol 52:758-765.

32. Ravenscroft N, Omar A, Hlozek J, Edmonds-Smith C, Follador R, Serventi F, Lipowsky G, Kuttel MM, Cescutti P, Faridmoayer A. 2017. Genetic and structural elucidation of capsular polysaccharides from Streptococcus pneumoniae serotype 23A and 23B, and comparison to serotype 23F. Carbohydr Res 450:19-29.

33. Richards JC, Perry MB. 1987. Structure of the specific capsular polysaccharide of 
Streptococcus pneumonia type 23F (American type 23). Biochem Cell Biol 66:758-771.

436

437
34. Duda KA, Petersen S, Holst O. 2016. Structural characterization of the lipoteichoic acid isolated from Staphylococcus sciuri W620. Carbohydr Res 430:44-47.

35. Ciucanu I, Kerek F. 1984. A simple and rapid method for the permethylation of carbohydrates. Carbohydr Res 131:209-217.

36. LOWRY OH, Roberts NR, KY L, M-L W, AL F. 1953. The quantitative histochemistry of brain. I. Chemical methods. J Biol Chem 207:1-17.

37. Gerwig GJ, Kamerling JP, Vliegenthart JFG. 1979. Determination of the absolute configuration of monosaccharides in complex carbohydrates by capillary g.l.c. Carbohydr Res 77:1-7.

38. Carver TJ, Rutherford KM, Berriman M, Rajandream MA, Barrell BG, Parkhill J. 2005. ACT: The Artemis comparison tool. Bioinformatics 21:3422-3423. 
Table 1 Results of monosaccharides compositional analysis, phosphate, methylation and absolute configuration analysis

\begin{tabular}{|c|c|c|c|c|c|c|}
\hline Serotype & $\begin{array}{c}\text { Rha } \\
\text { (nmol/mg) }\end{array}$ & $\begin{array}{c}\text { Glc } \\
\text { (nmol/mg) }\end{array}$ & $\begin{array}{c}\text { Gal } \\
(\mathrm{nmol} / \mathrm{mg})\end{array}$ & $\begin{array}{c}\mathrm{PO}_{4} \\
\text { (nmol/mg) }\end{array}$ & Linkage type & $\begin{array}{c}\text { L/ D- } \\
\text { configuration }\end{array}$ \\
\hline 16F CPS & 1545 & 1276 & - & 1770 & \multirow{2}{*}{$\begin{array}{l}\text { 2-linked Rha, 4-linked Glc, } \\
\text { 3-linked Glc }\end{array}$} & \multirow{2}{*}{$\begin{array}{l}\text { L-Rha, } \\
\text { D-Glc }\end{array}$} \\
\hline Ratio & 1.2 & 1.0 & - & 1.4 & & \\
\hline 16A CPS & 1455 & 686 & 2005 & 942 & \multirow{2}{*}{$\begin{array}{l}\text { 1,2-linked Rha, 1,3-linked } \\
\text { Rha, 4-linked Glc, 3-linked } \\
\text { Glc, 1,3-linked-Galf, 1,2,3- } \\
\text { linked Gal }\end{array}$} & \multirow{2}{*}{$\begin{array}{l}\text { L-Rha, } \\
\text { D-Glc, } \\
\text { D-Gal }\end{array}$} \\
\hline Ratio & 2.1 & 1.0 & 2.9 & 1.4 & & \\
\hline
\end{tabular}

Table $2{ }^{1} \mathrm{H}$ and ${ }^{13} \mathrm{C}$ NMR chemical shifts ( $\delta$, ppm) assignment of sonicated $16 \mathrm{~F}$ CPS, de-OAc $16 \mathrm{~F}$

CPS and de-P-Gro 16F CPS repeat unit as well as important HMBC/NOE correlations

\begin{tabular}{|c|c|c|c|c|c|c|c|c|}
\hline Sample & Residue & 1 & 2 & 3 & 4 & 5 & 6 & $\begin{array}{l}\mathrm{HMBC} / \\
\text { NOE }\end{array}$ \\
\hline \multirow{17}{*}{$\begin{array}{l}\text { Sonicated } \\
16 F \text { CPS }\end{array}$} & \multirow{6}{*}{$\begin{array}{l}\text { 3)- } \alpha-\text { Rhap-(1- } \\
\text { A } \\
\text { 3)- } \beta-\text { Rhap-(1- } \\
\text { B }\end{array}$} & 5.107 & 4.268 & 3.964 & 4.110 & 4.128 & 1.286 & A1-C3 \\
\hline & & 100.69 & 70.56 & 80.99 & 75.72 & 68.33 & 17.34 & \\
\hline & & 5.037 & 5.634 & 3.866 & 3.504 & 3.506 & 1.350 & B1-D4 \\
\hline & & 99.63 & 68.92 & 75.25 & 71.15 & 72.67 & 17.22 & \\
\hline & & \multicolumn{6}{|c|}{ OAc : 2.154 / 20.74} & \\
\hline & & \multicolumn{6}{|c|}{$\mathrm{C}=\mathrm{O}: 174.07$} & B2 \\
\hline & \multirow{2}{*}{$\begin{array}{c}\text { 3)- } \alpha-\mathrm{Glc} p-(1- \\
\text { C }\end{array}$} & 5.000 & 3.657 & 3.788 & 3.543 & 3.985 & 4.058 & C1-B3 \\
\hline & & 95.18 & 71.91 & 79.94 & 67.98 & 71.15 & 64.70 & \\
\hline & \multirow{3}{*}{$\begin{array}{c}\text { 4)- } \beta-G l c p-(1- \\
\text { D }\end{array}$} & 4.536 & 3.373 & 3.580 & 3.654 & 3.447 & $3.755 / 3.860$ & D1-A3 \\
\hline & & 104.56 & 73.61 & 75.48 & 77.68 & 74.66 & 61.13 & \\
\hline & & 3.921/ & 3874 & $3.666 / 3.646$ & & & & \\
\hline & \multirow{2}{*}{$\mathrm{P}_{1}-1-\mathrm{Gro}$} & 3.855 & & /3.588 & & & & \\
\hline & & 66.92 & 71.26 & 62.70 & & & & \\
\hline & $\mathrm{P}_{1}$ & \multicolumn{6}{|c|}{0.6031} & A4 \\
\hline & \multirow{2}{*}{$\mathrm{P}_{2}$-1-Gro } & 3.874 & 3.874 & $\begin{array}{c}3.666 / 3.646 \\
/ 3.588\end{array}$ & & & & \\
\hline & & 67.04 & 71.26 & 62.70 & & & & \\
\hline & $\mathrm{P}_{2}$ & & & 1.22 & & & & C6 \\
\hline \multirow{8}{*}{$\begin{array}{c}\text { de-OAc } \\
16 \mathrm{~F}\end{array}$} & \multirow{2}{*}{$\begin{array}{c}\text { 3)- } \alpha-\text { Rhap- }(1- \\
\text { A }\end{array}$} & 5.116 & 4.320 & 4.010 & 4.150 & 4.164 & 1.292 & A1-C3 \\
\hline & & 100.81 & 70.44 & 80.88 & 76.19 & 68.33 & 17.22 & \\
\hline & \multirow{2}{*}{$\begin{array}{l}\text { 3)- } \beta-\text {-Rhap-(1- } \\
\text { B }\end{array}$} & 4.850 & 4.269 & 3.670 & 3.473 & 3.417 & 1.324 & B1-D4 \\
\hline & & 100.92 & 67.75 & 78.30 & 70.79 & 72.67 & 17.22 & \\
\hline & \multirow{2}{*}{$\begin{array}{c}\text { 3)- } \alpha-\mathrm{Glc} p-(1- \\
\text { C }\end{array}$} & 5.063 & 3.700 & 3.869 & 3.575 & 4.088 & 4.117/4.094 & C1-B3 \\
\hline & & 96.00 & 72.20 & 80.06 & 67.98 & 71.26 & 64.93 & \\
\hline & \multirow{2}{*}{$\begin{array}{c}4)-\beta-G l c p-(1- \\
\text { D }\end{array}$} & 4.583 & 3.397 & 3.653 & 3.653 & 3.508 & 3.836/3.887 & D1-A3 \\
\hline & & 104.56 & 73.73 & 75.60 & 77.24 & 74.90 & 61.30 & \\
\hline
\end{tabular}




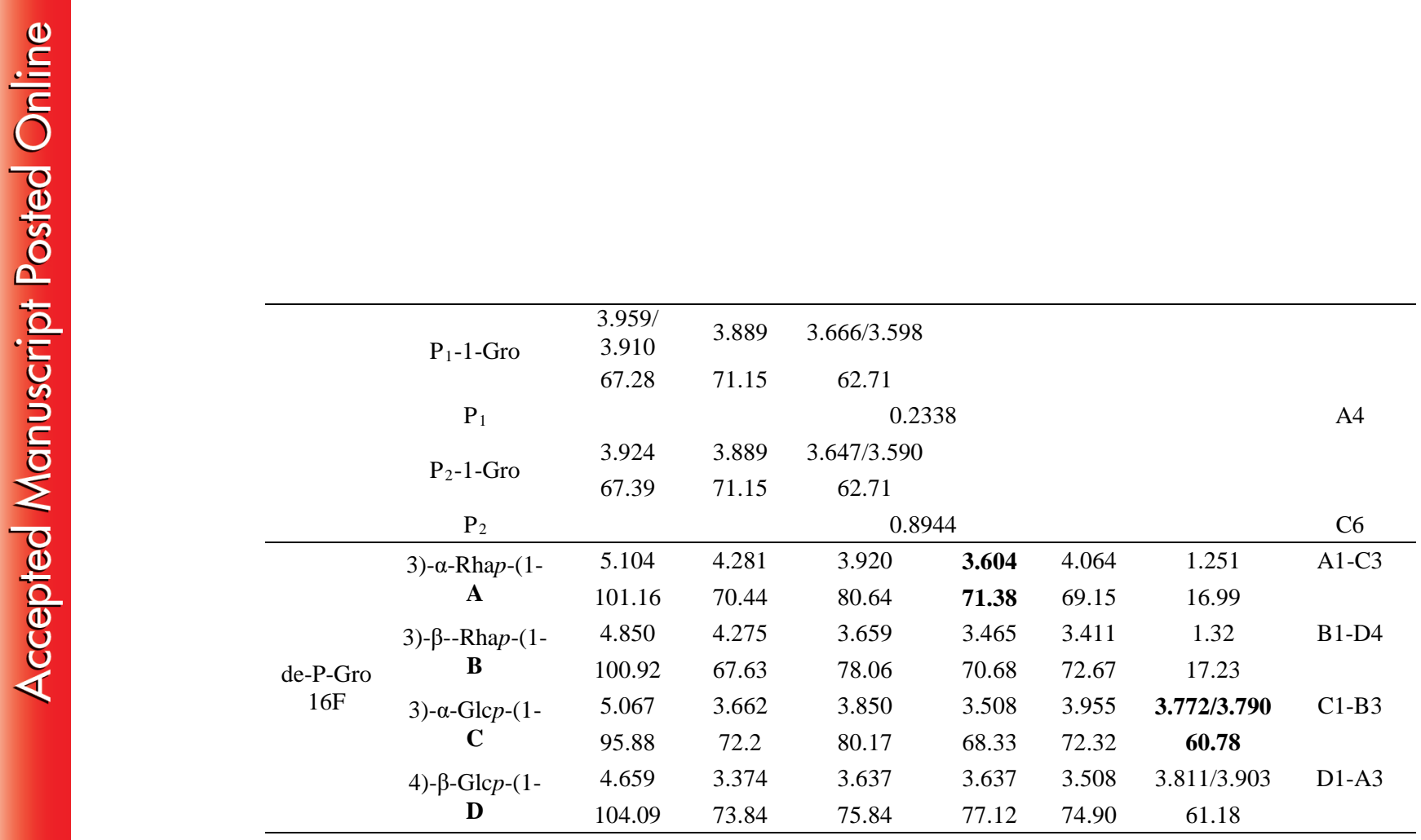

452 Table $3{ }^{1} \mathrm{H}$ and ${ }^{13} \mathrm{C}$ NMR chemical shifts $(\delta$, ppm) assignment of native 16A CPS, de-OAc 16A and 453 de-P-Gro CPS repeat unit as well as important HMBC/NOE correlations

\begin{tabular}{|c|c|c|c|c|c|c|c|c|}
\hline Sample & Residue & 1 & 2 & 3 & 4 & 5 & 6 & $\begin{array}{c}\text { HMBC/ } \\
\text { NOE }\end{array}$ \\
\hline \multirow{21}{*}{$\begin{array}{l}\text { Native } \\
\text { 16A CPS }\end{array}$} & \multirow{4}{*}{$\begin{array}{c}\text { 3)- } \beta-\text { Galf-2- } \\
\text { OAc- }(1- \\
\text { A } 70 \%\end{array}$} & 5.395 & 5.155 & 4.407 & 4.250 & 3.966 & $3.706 / 3.674$ & A1-D3 \\
\hline & & 107.55 & 82.45 & 83.27 & 83.27 & 70.6 & 63.27 & \\
\hline & & \multirow{2}{*}{\multicolumn{6}{|c|}{$\begin{array}{c}\text { OAc: } 2.119 / 20.75 \\
\text { C=O: } 173.45\end{array}$}} & \\
\hline & & & & & & & & A2 \\
\hline & \multirow{2}{*}{$\begin{array}{c}\text { 3)- } \beta \text {-Galf-(1- } \\
\text { A' } 30 \%\end{array}$} & 5.2406 & 4.345 & 4.267 & 4.191 & 3.952 & $3.706 / 3.674$ & A'1-D'3 \\
\hline & & 109.66 & 80.45 & 85.14 & 82.45 & 70.83 & 63.27 & \\
\hline & \multirow{2}{*}{$\begin{array}{l}2)-\alpha-\text { Rhap- }(1- \\
\text { B }\end{array}$} & 5.192 & 4.057 & 3.949 & 3.489 & 3.805 & 1.29 & B1-C3 \\
\hline & & 100.98 & 78.46 & 70.48 & 72.71 & 69.78 & 17.23 & \\
\hline & \multirow{2}{*}{$\begin{array}{l}\text { 3)- } \alpha-\text { Galp-(1- } \\
\text { C }\end{array}$} & 5.131 & 3.981 & 3.993 & 4.113 & 4.328 & 3.960 & C1-F3 \\
\hline & & 96.29 & 68.37 & 76.70 & 68.96 & 70.01 & 64.44 & \\
\hline & \multirow{2}{*}{$\begin{array}{l}\text { 3)- } \alpha-\text { Rhap-(1- } \\
\text { D }\end{array}$} & 4.947 & 4.164 & 3.895 & 3.533 & 3.753 & 1.254 & D1-B2 \\
\hline & & 102.27 & 70.48 & 77.87 & 71.54 & 69.78 & 17.23 & \\
\hline & D’3 & \multicolumn{6}{|c|}{3.864 /78.11 } & \\
\hline & \multirow{2}{*}{$\begin{array}{c}\text { 4)- } \beta \text {-Glcp-(1- } \\
\mathbf{E}\end{array}$} & 4.673 & 3.340 & 3.668 & 3.665 & 3.58 & $3.962 / 3.830$ & \\
\hline & & 102.15 & 73.18 & 74.70 & 79.04 & 75.29 & 60.45 & E1-A3 \\
\hline & $\mathbf{E}^{\prime}$ & 4.637/102.39 & & & & & & \\
\hline & \multirow{2}{*}{$\begin{array}{l}\text { 3)- } \beta-\text { Galp-(1- } \\
\text { F }\end{array}$} & 4.524 & 3.653 & 3.771 & 4.147 & 3.714 & $3.744 / 3.775$ & \\
\hline & & 103.33 & 70.01 & 78.22 & 65.56 & 75.53 & 61.39 & F1-E4 \\
\hline & \multirow{2}{*}{ Gro-1-P } & $3.901 / 3.845$ & 3.881 & $3.647 / 3.590$ & & & & \\
\hline & & 66.79 & 71.19 & 62.57 & & & & \\
\hline & $\mathrm{P}$ & 0.9144 & & & & & & C6 \\
\hline
\end{tabular}




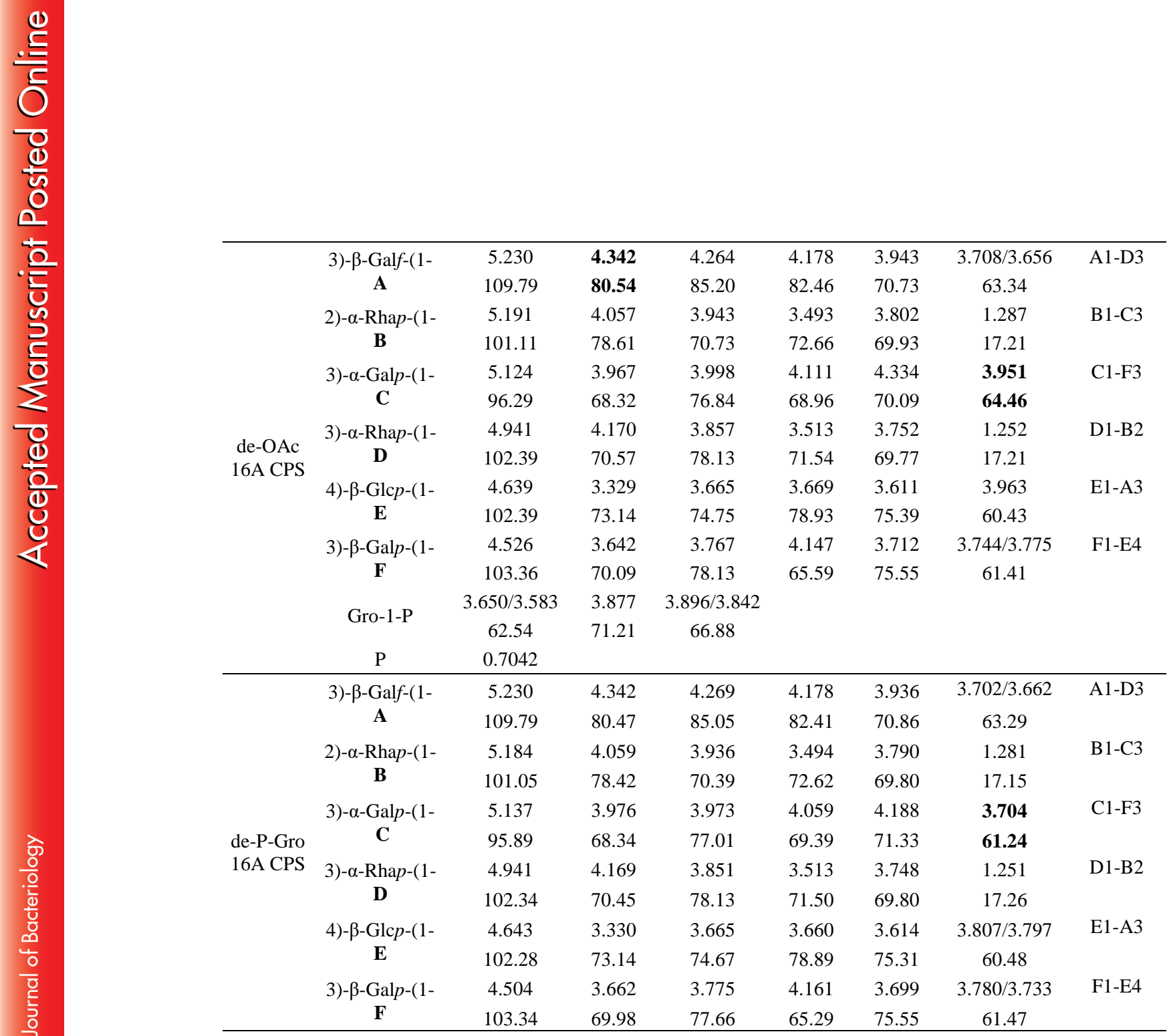

454 Table 4 Serotype 16F and 16A CPS biosynthetic genes, their predicted functions or products,

455 structures they catalysed and related serotypes containing same genes.

\begin{tabular}{|c|c|c|c|c|c|c|c|}
\hline \multirow[b]{2}{*}{ Gene $^{a}$} & \multirow{2}{*}{$\begin{array}{l}\text { No. of } \\
\text { occurence } \\
\text { of gene }\end{array}$} & \multirow[b]{2}{*}{ Product/Fuction } & \multicolumn{3}{|c|}{ Structure } & \multicolumn{2}{|c|}{ Serotypes containing the gene } \\
\hline & & & donor & $\begin{array}{l}\text { linka } \\
\text { ge }\end{array}$ & acceptor & CPS Structure known & $\begin{array}{c}\text { CPS } \\
\text { Structure } \\
\text { unknown }\end{array}$ \\
\hline$w c h F$ & 27 & GT & L-Rhap & $\beta 1-4$ & $\beta$-D-Glcp & $\begin{array}{c}\text { 2,7F,7A,7B,17F,18F,18A, } \\
\text { 18B,18C,22F,23F,27,32F,32 } \\
\text { A,16F }\end{array}$ & \\
\hline \multirow{2}{*}{ wciU } & \multirow{2}{*}{7} & \multirow{2}{*}{ GT } & D-GlcpNAc & $\alpha 1-3$ & $\beta$-L-Rhap & $18 \mathrm{~A}$ & \multirow{2}{*}{$28 \mathrm{~F}, 28 \mathrm{~A}$} \\
\hline & & & D-Glcp & $\alpha 1-3$ & $\beta$-L-Rhap & 18F,18B,18C,16F & \\
\hline$w c x N$ & 3 & GT & L-Rhap & $\alpha 1-3$ & $\alpha$-D-Glcp & $16 F$ & $28 \mathrm{~F}, 28 \mathrm{~A}$ \\
\hline$w c x M$ & 4 & acetyl transferase & \multicolumn{3}{|c|}{$\beta$-L-Rhap-2-OAc } & $18 \mathrm{~F}, \mathbf{1 6 F}$ & $28 \mathrm{~F}, 28 \mathrm{~A}$ \\
\hline
\end{tabular}




\begin{tabular}{|c|c|c|c|c|c|c|c|}
\hline$w z y 27^{b}$ & 1 & polymerase & $\beta$-D-Gl & $1,3)-\alpha-1$ & L-Rhap & $16 \mathrm{~F}$ & \\
\hline \multirow{2}{*}{ gct } & \multirow{2}{*}{13} & \multirow{2}{*}{$\begin{array}{l}\text { glycerol-1-phosphate } \\
\text { biosynthetic protein }\end{array}$} & \multicolumn{3}{|c|}{ P-1-Gro } & $\begin{array}{c}\text { 11A,11C,11D,11E,18F, } \\
\text { 18A,18B,18C,45,16F,16A }\end{array}$ & \\
\hline & & & \multicolumn{3}{|c|}{ Rib-ol-1-P } & 11B,11F(truncated $g c t$ ) & \\
\hline$w c x P$ & 3 & $\begin{array}{c}\text { sugar/polyalcohol } \\
\text { phosphate transferase }\end{array}$ & \multicolumn{3}{|c|}{$\begin{array}{l}\text { D-Glcp-6-P-1-Gro / } \\
\text { L-Rhap-4-P-1-Groc }\end{array}$} & $16 \mathrm{~F}$ & $28 \mathrm{~F}, 28 \mathrm{~A}$ \\
\hline$w c x Q$ & 3 & $\begin{array}{c}\text { sugar/polyalcohol } \\
\text { phosphate transferase }\end{array}$ & \multicolumn{3}{|c|}{$\begin{array}{l}\text { D-Glcp-6-P-1-Gro / } \\
\text { L-Rhap-4-P-1-Groc }\end{array}$} & $16 \mathrm{~F}$ & $28 \mathrm{~F}, 28 \mathrm{~A}$ \\
\hline $\begin{array}{l}\text { wchK } \\
\text { wchJ }\end{array}$ & 13 & GT enhancer & D-Galp & $\beta 1-4$ & $\beta$-D-Glcp & $\begin{array}{c}\text { 11F,11A,11B,11C,11D, } \\
\text { 11E,13,14,15F,15A,15B, } \\
\text { 15C,16A }\end{array}$ & \\
\hline wсуK & 7 & GT & D-Galp & $\alpha 1-3$ & $\beta$-D-Gal $p$ & $\begin{array}{c}11 \mathrm{~F}, 11 \mathrm{~A}, 11 \mathrm{~B}, 11 \mathrm{C}, 11 \mathrm{D}, \\
\text { 11E,16A }\end{array}$ & \\
\hline$w c x S$ & 2 & GT & L-Rhap & $\alpha 1-3$ & $\alpha$-D-Galp & 45,16A & \\
\hline$w c x T$ & 1 & hypothetical protein & L-Rhap & $\alpha 1-2$ & $\alpha$-L-Rhap & 16A & \\
\hline \multirow{4}{*}{$w c i B$} & \multirow{4}{*}{25} & \multirow{4}{*}{ GT } & \multirow{4}{*}{ D-Galf } & \multirow{4}{*}{$\beta 1-3$} & $\beta$-D-Galp & $\begin{array}{c}\text { 10F,10A,10B,10C,29,39,47F, } \\
47 \mathrm{~A}\end{array}$ & \multirow{4}{*}{43} \\
\hline & & & & & $\beta$-D-Glcp & $\begin{array}{l}\text { 17A,20A,20B,33F,33A,35F, } \\
\text { 35A,35B,35C,41F,41A,42 }\end{array}$ & \\
\hline & & & & & $\alpha$-D-Glcp & 34 & \\
\hline & & & & & $\alpha$-L-Rhap & 16A & \\
\hline
\end{tabular}

37(synthase pathway)

\begin{tabular}{|c|c|c|c|c|}
\hline wzy $15^{b}$ & & Polymerase & $\beta$-D-Glcp-(1,3)- $\beta$-D-Gal $f$ & $16 \mathrm{~A}$ \\
\hline \multirow{4}{*}{ wciG } & \multirow{4}{*}{16} & \multirow{4}{*}{ acetyl transferase } & $\beta$-D-Galf-2-OAc & $\begin{array}{c}\text { 20A,20B,33F,33A,33B,33D, } \\
\text { 35F,35A,35B,47F,16A }\end{array}$ \\
\hline & & & $\beta$-D-Glcp-2,3-OAc & 13 \\
\hline & & & $\beta$-D-Galf-5,6-OAc & $\begin{array}{l}\text { 42(containing wciG and } \\
\text { wciE) }\end{array}$ \\
\hline & & & NO OAc & $\begin{array}{l}\text { 35C(containing wciG and } \\
\text { wciE), 10F,10C }\end{array}$ \\
\hline
\end{tabular}

\begin{tabular}{llcllll}
\hline$w c x R$ & 1 & $\begin{array}{c}\text { sugar/polyalcohol } \\
\text { phosphate transferase }\end{array} \quad$ Gro & $1-\mathrm{P}-4$ & $\alpha$-D-Galp & $\mathbf{1 6 A}$
\end{tabular}

457 galactofuranose synthetic genes are not included.

$458{ }^{\mathrm{b}}$ The wzy27 and wzy15 mean that they were belong to Wzy homology groups 27 and 15,

459 respectively.

$460{ }^{\mathrm{c}}$ The specific functions of two sugar/polyalcohol phosphate transferases (WcxP and WcxQ) can not 461 be distinguished. 
Table 5 Cross-reactions between serogroup 16 and serogroup 28 using Quellung reaction

\begin{tabular}{ccccccccccccc}
\hline \multirow{2}{*}{ serotype } & \multicolumn{10}{c}{ factor sera } \\
\cline { 2 - 11 } & $16 \mathrm{~b}$ & $16 \mathrm{c}$ & $28 \mathrm{~b}$ & $28 \mathrm{c}$ & $11 \mathrm{~b}$ & $11 \mathrm{c}$ & $11 \mathrm{f}$ & $11 \mathrm{~g}$ & $23 \mathrm{~b}$ & $23 \mathrm{c}$ & $23 \mathrm{~d}$ \\
\hline $16 \mathrm{~F}$ & +++ & - & +++ & - & - & +++ & - & - & - & - & - \\
$16 \mathrm{~A}$ & - & +++ & - & - & - & +++ & - & - & - & - & - \\
$28 \mathrm{~F}$ & - & - & +++ & - & - & - & - & - & - & - & +++ \\
$28 \mathrm{~A}$ & - & - & - & +++ & - & - & - & - & - & - & +++ \\
\hline
\end{tabular}

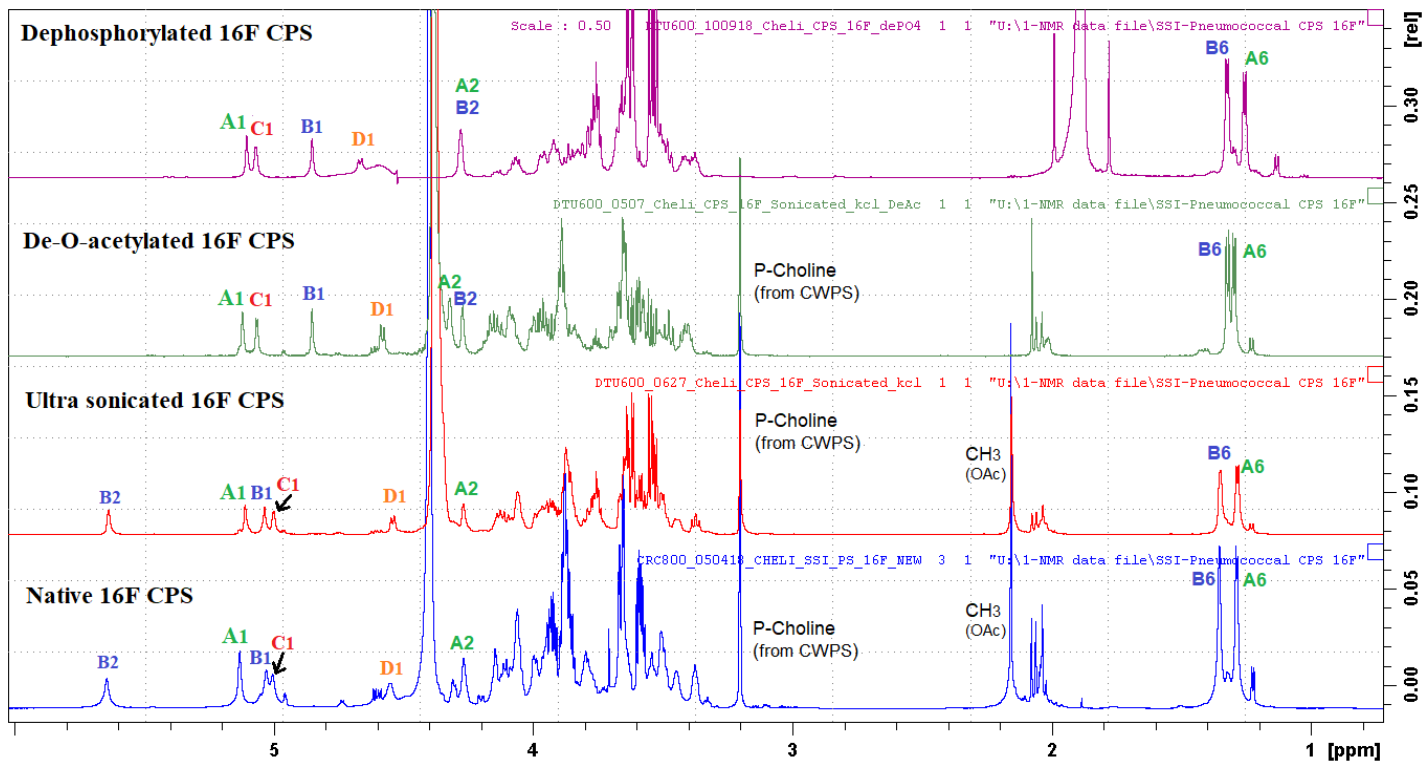

464 Fig. 1 Expansion of ${ }^{1} \mathrm{H}$ spectra of native16F CPS, Ultra sonicated16F CPS, de-OAc 16F CPS and 465 de-P-Gro 16F CPS 
A

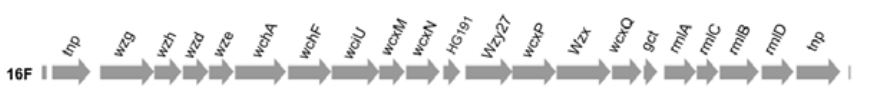

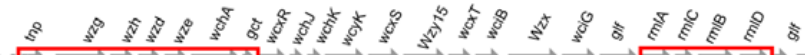

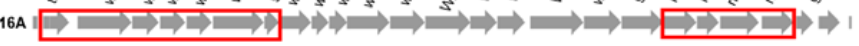

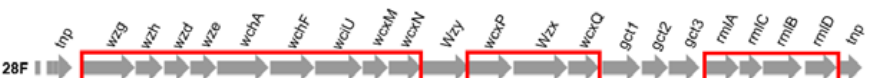

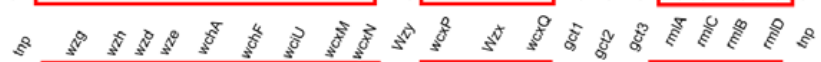

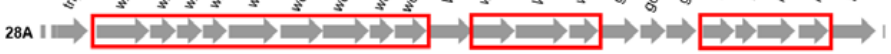
$11 \mathrm{~A}$

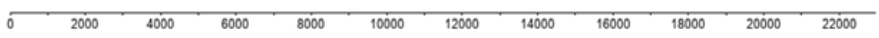
blue arrow;
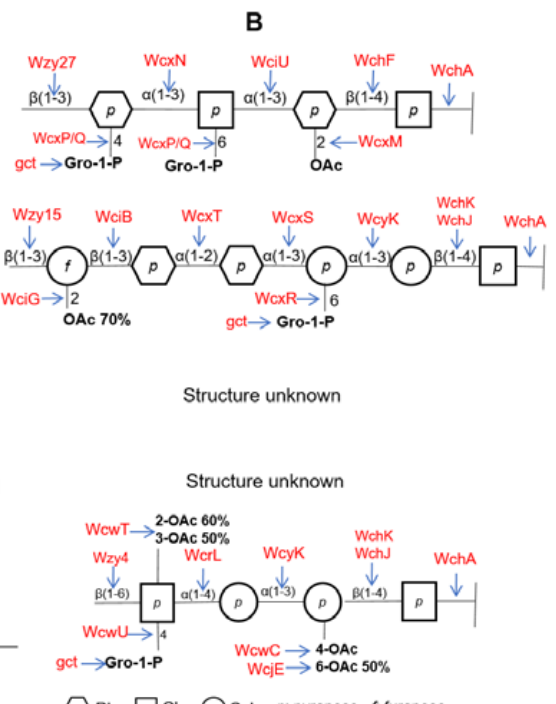

$\bigcirc$ Rha $\square$ Glc $\bigcirc$ Gal $p$ : pyranose $f$ furanose

Fig. 4 Comparison of serogroup 16 CPS biosynthetic gene loci and repeat unit structures with other serotypes. (A) cps gene loci of S. pneumonia serogroup 16 and related serotypes; Red frames highlight genes highly similar to 16F cps gene locus; (B) CPS repeat unit structures and biosynthetic enzymes(red characters) that are responsible for corresponding structures indicted by 